\title{
A spatiotemporal coding mechanism for background independent recognition of odors
}

\author{
Baranidharan Raman \\ From 1st International Workshop on Odor Spaces \\ Hannover, Germany. 4-7 September 2013
}

Sensory stimuli often evoke temporal patterns of spiking activity across a population of neurons in the early processing stages. These neural responses are considered a 'temporal code' if they change on a timescale that is different than the stimulus variations that caused them and when they convey useful information about the stimulus. A fundamental problem in sensory neuroscience is determining what stimulus-specific information is encoded by dynamic patterns of ensemble neural activity and whether this information is behaviorally relevant. Furthermore, since the same stimulus can be encountered in a variety of ways in natural environments, what attributes of the spatiotemporal population responses are invariant to any or all such variations in stimulus features?

In this talk, I will describe how dynamic processing of odor signals allows an invertebrate olfactory system to recognize odorants in a background-independent manner. I will first discuss how freshly introduced odors are received by olfactory receptor neurons in the locust antenna (Schistocerca americana), and then show how the generated sensory input is transformed, step-by-step, into background-invariant neural representations. I will conclude with a brief discussion of correlations between temporally patterned neural activity and behavioral performance of locusts in an odor recognition task.

Submit your next manuscript to BioMed Central and take full advantage of:

- Convenient online submission

- Thorough peer review

- No space constraints or color figure charges

- Immediate publication on acceptance

- Inclusion in PubMed, CAS, Scopus and Google Scholar

- Research which is freely available for redistribution
C Biomed Central 